特集 $3^{*}$

\title{
教室に抢ける特発性炎症性腸疾患の
}

手術適応と治療成績について

\author{
東京大学第 1 外科 \\ 武藤徹一郎上谷潤二郎草間悟

\section{RESULTS OF SURGICAL TREATMENT OF IDIOPATHIC INFLAMMATORY BOWEL DISEASE}

\section{Tetsuichiro MUTO, Junjiro KAMIYA and Satoru KUSAMA}

Department of Surgery, University of Tokyo, Tokyo

\begin{abstract}
教室に打ける潰煌性大腸炎拉よび Crohn 病の手術適応ならびに術後成績について述べた。潰煬性大腸 炎は基本的には内科的には治療すべき疾患であるが，手術が必要な場合にるできる限り直腸を温存する手 漱を選択すべきであり，それが可能で西ると考兄られた．残存值腸の炎症再燃の治療にはステロイド坐薬 が有効であった，教空に批ける直腸温存術 8 例の成績は良好で再手術を行った例はなかった。

Crohn 病に対する手術は狭窄，瘦孔などの合併症に対して行われることが多かった。教室に拈ける手術 成績は11例中再発率36\%，死亡率18\%で，死亡が再発に関係していたと仮定すれば再発率は $54 \%$ になる. Crohn 病の手術適応，術式選択にはいまだ問題点が多く，今後症例を集積して再検討する必要があると考 えられた。
\end{abstract}

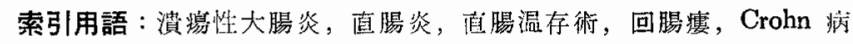

1.はじめに

潰瘍性大晹炎和よび Crohn 病は特発性炎症性腸疾患 の中の代表的疾患であり，その病因診断，治療に関する 報告は欧米では枚挙に䘿がない。わが国でも近年ようや くこの方面への関心が高まるにつれて, 症例数も增加し て消化器関係の日常診療の中でも常に考虑に入れて和か ねばならない疾患になってきている.この機会に教室に お斿る両疾患の治療成續を整理するとともに，现時点に 和㲿るわれわれの治療方向につ、ての考光を述べたい。

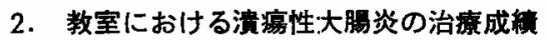

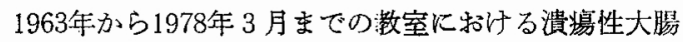
炎の経験例数は77例で，去の中:全大腸炎型18例，区域性 大腸炎型 2 例に手術が行われた（表 1).男女比は45：32

* 第12回日消外総会シンポ III 特発性炎症性腸疾患
表 1 潰湯性大腸炎

\begin{tabular}{c|c}
\hline 直 腸 炎 & 33 \\
\hline 左側大腸炎 & 14 \\
\hline 区域性大腸炎 & $\underline{2}$ \\
\hline 全大腸 炎 & $28(\underline{18}+10)$ \\
\hline 計 & 77 \\
\hline
\end{tabular}

T. U. H. $1963 \sim 1978.3$

$=1: 0.71$, 平均年龄は30歳であった，手術例の内訳は 表 2 の如くで，死亡例 3 （死亡率15\%）であった。直晹 温存術は一期的あるいは二期的飞 8 例飞行われ，近い将 来に直腸温存術を予定している例が 1 例ある。

回腸瘦造設術の行方れた症例の内訳は図 1 の如くであ る. 生存例 6 例とも健在であるが, 症例 2 は12年後に胆 石症を作発した．3例の死亡例はいずれも重症あるいは 
表 2 潰瘍性大渴炎乎術例（男12：女8）

\begin{tabular}{|c|c|}
\hline 全大腸切除十回晹漊 & 5 (死亡-1) \\
\hline Hartmann & 3 (死亡 2 ) \\
\hline 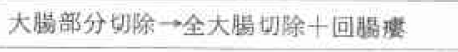 & 1 \\
\hline 全結腸切除十回晹直腸吻合 & 7 \\
\hline 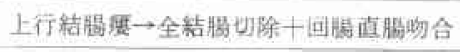 & 1 \\
\hline$n-7^{\prime}$ 回期瘎 $\cdots \cdots$ & 1 \\
\hline 大腸部分切除十結腸摟 & 1 \\
\hline \multirow[t]{2}{*}{ 結腸部分切除 } & 1 \\
\hline & 20 \\
\hline
\end{tabular}

1978. 3

活動期に手術が行われて拉り，2 例は術直後（2 週間） に, 1 例は 3 年後に死亡した.

㨁腸温存術の行われた症例の内訳汢図 2 の如くであ る.回腸瘦逆設の行われた症例に比べて, 重症度は低 く，より選択された時期に手術が行われていた。症例 6 を除いて一期的に全結腸切除十回腸直腸吻合が行われ た. 吻合法は端一端, 端一例, 逆 6 字型などが試みられ たが，排便回数と吻合法の間に特別な関係はみられなか
った。症例 7 は合併した胆管周囲资，肝障害のために通 院加療中である. 直晹温存術後の予後は図 3 の如くで, 8 例中 6 例に少なくと‡1 回の再燃が認められた. 再然 例はいずれあステロイソ坐葉によって治療し，好成績を 収めて打り再切除例はない。

\section{3. 教室における Crohn 病の治療成縝}

教室に括ける Crohn 病確診例の手術成績は図 4 の如 くであった．男女比は9：2で1例を除く全例に虫垂切 除が行われていた。いずれる術前に確定診断はついて拉 らず，切除標本の組織学的検索によって Crohn 病の㟝 断がつけられた。半数以上が回盲部に病変の中心があ り，小晹のみに病変の認められた例はなかった。死亡2 例 (死亡率18\%)，再発 4 例（再発率36\%) であり，死 亡例を再発によると考次れば再発率は $54 \%$ となる.平均 作龄は29嵗であった。

\section{4. 考 察}

1）溃場性大腸炎の㐿術適応について

潰凗性大腸炎は原則的には内科的に治療すべき疾患で あると考えられ，手術的治療が必要となるのは30\%以下 にすぎない，手術が必要となる例は注とんど全大腸炎型 に限られており，左側大腸炎型，直腸资型で手術適応の

図 1 全大腸切除十回脂瘘造設の症例

\begin{tabular}{|c|c|c|c|c|c|c|c|c|}
\hline & $\begin{array}{l}\text { AGE } \\
\text { SEX }\end{array}$ & $\begin{array}{l}\text { SYMP- - } \\
\text { DIAG. }\end{array}$ & $\begin{array}{l}\text { SYMP. - } \\
\text { SURG. }\end{array}$ & SEVERITY & $\begin{array}{l}\text { STEROID USED } \\
\text { PERIOD }\end{array}$ & $\begin{array}{l}\text { SIEROID JUST } \\
\text { BEFORE SURG. }\end{array}$ & $\begin{array}{l}\text { OPERATION \& } \\
\text { RESULT }\end{array}$ & \\
\hline 1. 12960 & $32 n$ & $8 \pi$ & $4 y$ & vilL. -5 & $>6 n$ & No & 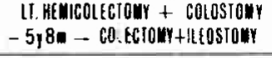 & WELI \\
\hline 2. 630398 & $19 \AA$ & $2 y 8 m$ & $5 y$ & $\begin{array}{lr}\text { SEY. } & 2 \\
\text { ESR. } & 30\end{array}$ & $>2 y$ & pred. $15 \mathrm{~m}_{\mathrm{g}}$ & $\begin{array}{l}\text { Proctocolectolly + ILEOSTOHY } \\
\qquad 1 P+11\end{array}$ & WELL \\
\hline 3.640284 & $23 n$ & 1n & $3 m$ & $\begin{array}{lr}\text { SEY. } & 3 \\
\text { ESR. } & 42\end{array}$ & $<1$ m & No & $\begin{array}{c}\text { colectouy(muRImakn) } \\
\text { + ileostony }\end{array}$ & WELL \\
\hline 4.650550 & $24 I I$ & 1y & $4 y$ & $\begin{array}{lr}\text { SEY. } & 1 \\
\text { ESR. } & 27\end{array}$ & $>$ iy in & No & $p+1$ & WE LI \\
\hline 5.650780 & 1811 & $2 y$ & $5 y$ & $\begin{array}{lr}\text { SEY. } & 1 \\
\text { ESR. } & 75\end{array}$ & $3 y$ & no & $P+1$ & WELIL \\
\hline 6.730146 & 251 & $3 y$ & $2 \pi$ & Nod -1 & $2 \pi$ & $\begin{array}{l}\text { hyd. } 200 \mathrm{mg} \\
\text { onema }\end{array}$ & $P+1$ & WELI \\
\hline
\end{tabular}

\begin{tabular}{|c|c|c|c|c|c|c|c|c|}
\hline 7. 830177 & $24 f$ & 2* & 3n & SFY. 3 & $2 w$ & $d n$ & $-2 \pi=$ & QIED \\
\hline 8. 690019 & $23 t$ & $4 \pi$ & 2y & $\begin{array}{l}\text { Moo. }-3 \\
\text { ESR. } 37\end{array}$ & is & 110 & 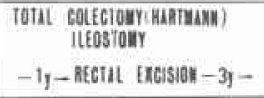 & OIED \\
\hline 9.710535 & $22 F$ & $2 m$ & $6 y 7 m$ & $\begin{array}{rr}\text { SEY. } 0 \\
\text { ESA. } 63\end{array}$ & $4 m$ & $\begin{array}{l}\text { prit } \\
40 \mathrm{mb}\end{array}$ & $-2 v-$ & DIEO \\
\hline
\end{tabular}

TUH $1963.3-1978.2$

Severity の判定は田井の判定法によった。 
四 2 全結腸切除十回腸淔腸吻合の症例

\begin{tabular}{|c|c|c|c|c|c|c|c|c|c|}
\hline & AGE & SYMP:" & $\begin{array}{l}\text { SYMP. } \\
\text { SURG. }\end{array}$ & SEVERITY & $\begin{array}{l}\text { STEROID USED } \\
\text { PERIOD }\end{array}$ & $\begin{array}{l}\text { STEROID JUST } \\
\text { BEFORE SURG }\end{array}$ & $\begin{array}{l}\text { OPERETION } \\
\text { RESULT }\end{array}$ & $\begin{array}{l}\text { Freq. } \\
\text { Defocation }\end{array}$ & Rec \\
\hline 1. & $19 m$ & $6 m$ & $16 \mathrm{~m}$ & $\begin{array}{l}\text { MIL. } \\
\text { ESR } 3\end{array}$ & $>1 m$ & No & $\begin{array}{c}\text { ILOPROCTOSTOMY (I-P) } \\
\text { HE WELL }\end{array}$ & 2 & $?$ \\
\hline 2. 600256 & $34 m$ & $5 y$ & 8y10m & SEV. & $4 y$ & prod. $10 \mathrm{mo}$ & I-P (O) WEL & $7 \sim 8$ & 0 \\
\hline 3. $\operatorname{sen} 77$ & $2 a m$ & $4 m$ & $198 \mathrm{~m}$ & $\begin{array}{l}\text { MIL } \\
\text { ESR } 13\end{array}$ & $1 m 2 w$ & No & I-P & 4 & 3 \\
\hline I. 710141 & 465 & $7 y$ & $12 y$ & MIL & ly & No & ILEOSIGMOIDOSTOMY & $3-4$ & $n$ ? \\
\hline 5. 710551 & $25 \mathrm{~m}$ & $2 y 6 m$ & $4 y 4 m$ & MiL & $1 y 3 m$ & No & I-P & $2 \sim 3$ & 13 \\
\hline $\begin{array}{l}\text { 6. } 750026 \\
760006\end{array}$ & $24 F$ & $3 m$ & $3 y$ & $\begin{array}{ll}\text { MIL } & 0 \\
\text { ESR } & \text { 3t }\end{array}$ & $2 y 6 m$ & $\begin{array}{c}\text { pred. } 30 \mathrm{mg} \\
\downarrow \\
\text { rind. } 0.5 \mathrm{mg}\end{array}$ & 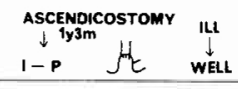 & $4 \sim 5$ & 1 \\
\hline 7. 760242 & 319 & $1 y 7 m$ & $4 y 2 m$ & $\begin{array}{l}\text { MOD } \\
\text { ESR } 13\end{array}$ & $6 m$ & pred. $20 \mathrm{mg}$ & I-p & $7 \sim 8$ & 0 \\
\hline 8. $76-1654$ & $19 m$ & $9 \mathrm{~m}$ & dy & $\begin{array}{l}\text { MHL } \\
\text { ESR : }\end{array}$ & $>7 \mathrm{~m}$ & NO & $1 \rightarrow \mathfrak{t}$ & $2 \sim 4$ & 1 \\
\hline
\end{tabular}

図 3 潰瘍性大腸炎に対する直腸温存術の成績

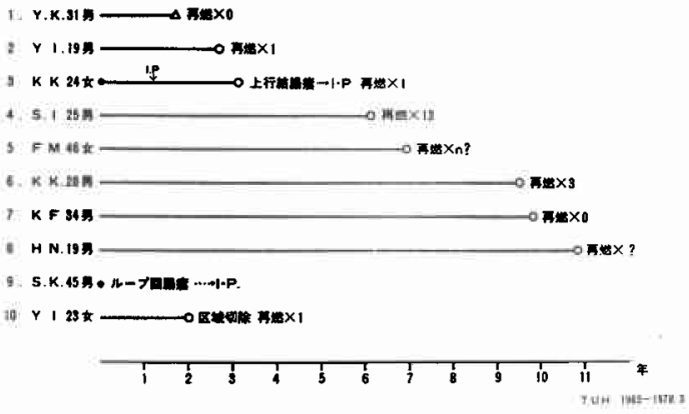

図 4 Crohn 病の手術成績

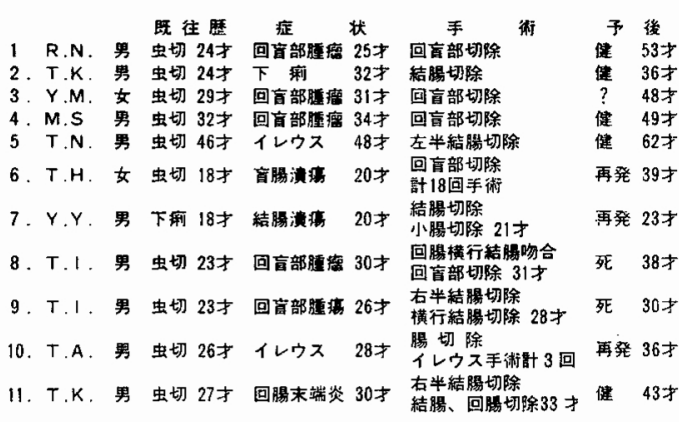

T.U.H. 1978.7
あることは極めて稀である1)。われわれの症例では区域 性大腸炎 2 例に手術が行われているが，罹患部位の炎症: が強く再燃をくり返すために手術的治療が行われたもの である。

手術には待期的手術と緊急手術があり，前者の適応は (1) 再然をくり返す. (2) 内科的治撩無效。(3) 全身的

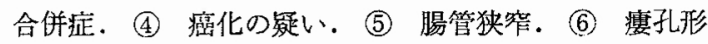
成. (7) 社会的適応などであり，後者の適応は(1) 大出 血，(2) 穿孔，(3) 中毒性巨大結腸症，(1) 重症型，(5) 急性電撃型などである ${ }^{2}$. 教室例は 1 例を除いて待期手 術で(1)(2)の適応が最も多かった。白鳥ら”の全国調査で 当待期的手術では(1)(2)が，緊急手術では(1)(3)が多い. 繁 念手術の死亡率は高いので, 内科的治療，とくにステロ イド治療に頼りすぎて手術の好期を逸することがないよ らに注意する必要がある。このためには内科と外科の緊 密な情報交換と協力体制が大切であると考点られる。表 3，4からも明らかなように, 症状 (粘血便) が出始め てから診断がつくまでに月または年の単位の時間が経過 している.一般的に潰癔性大腸炎は直腸炎から始まると 考学られて叔り ${ }^{3)}$ ，発病の初期に診断を確定して適切な 治療を行壳ぱ，手術的治療を必要とする症例は減少する であろらと考えられる、われわれの経験では，直腸炎が 上行性に左側結腸炎または全大腸炎に增悪するのは比較 
的短期間に起こることが多いようである．最近手術例が 隇少しているのは，早期猃断と適切な治療に負ら所が大 きいと考えられる.

手術適応があると考兄られた場合，次に問題となるの は手術々式の選択である。手術々式の選択は基本的には 回晹瘦造設と直腸温存の二者択一である（図 5 ). 前者に は全大腸切除による疾病の根絶といら長所の代償として 永久回腸瘦の負担といら短所が付加される．二度と再発 の可能性がなくなるが回瘍瘦による肉体的, 精神的ハン デイキャップは，患者の大多数が若年であるだけに無視 し難いものがある.後者の長所と短所は丁度その逆で，

図 5 Choice of Operative Proceidure

I. ILEOStOMY W1TH PROctocolectomy

2. ILEOSTOMY With SUBTOTAL COLECTOMY AND SUBSEQUENT RECTAL EXCISION

3. Ileostomy with SUBtotal COLECTOMY and SUBSEQUent ILEO-REC IAL ANASTOMOSIS

4. Colectomy and ileo-rctal anastomosis

\section{Defrianent II estany of sphineteresuving ejeration}

回瘍霋の負担がない代りに残存直腸への再然の可能性が 残されるが，最近では欧米です直腸温存術を指向する傾

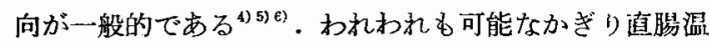
存の方針を採って怙り，1973年以後全大腸切除十回腸摜 造設は行っていない.いずれの術式を採るにしても一期 的に行ら場合と二期的に行う場合とがあり，全身状態が 悪い場合, 炎症が強い場合には二期的に行う方が安全で ある，直腸を温存する場合には直腸粘膜の炎症がないか 軽度であることが必要で, ステロイドの局所的療法（注 腸，坐薬）によって直腸病変の軽快を高率に得ることが 可能である.炎症が強くて一期的に吻合することが危険 な場合火は，S 状結腸以下を切除せずに mucous fistula にしてそこからステロイドの局所的療法を行い，炎症が 消退した時期に二期的に回腸直腸吻合を行ら．患者の将 来の生活を考觉て，できる限り直晹温存術を行兄るよう に努力すべきであると考党ている。しかし，残存直腸に 癌が発生する可能性がゼロではないので8, 患者との接 触は将来にわたって継続していかなければならない。

2）ステロイド離脱について

手術に際してステロイド療法から完全に離脱している ことが望ましいことは言うまですない，われわれの経験 では, 手術時にステロイド離脱をしていた例は直腸温存 例 5 例 $(62 \%)$, 回腸㿉例 5 例 (55\%) で大差はなかった が，死亡例 3 例中 2 例はステロイド大量投与中であり，
直腸温存例のステロイド投与中の 1 例には縫合不全が発 生した。

最近われわれの経験した 2 症例は，ステロイドの 2 年 余にわたる長期投与のために副腎皮質機能低下，moon face, acne, 骨粗䅗症, 筋萎縮, 糖尿病などの副作用が 著明で治療に難渋した。ステロイド（プレドニン20ng） 経口投与を減量すると大腸炎の症状が悪化し下痢, 下血 が増悪するために離脱はおるか減量も不河能だったので ある、本来ならば，ステロイドの副作用が著明になる前 に, 内科的治療無効の適応のもと乎術が行われるべき であったと考兄られる症例である(図303，9）。わ れわれはこの拝例に対して, ステロイド離脱の目的で翼 便流を遮断少るために上行結腸瘦あるいは回腸瘦を造設 した. ステロイドの減量開始にともない大腸炎の症状が 出現するが, 糞便流が遮断されているために下血, 分血 は著明とはならない.大腸炎に対してはステロイド注腸 を適富投与しつつ 8 カ月を費してプレドニン $20 \mathrm{mg}$ から リンデロン0.5mg まで减量することに成功し，14カ月 後に全結腸切除十回腸值腸吻合を行って, 歩行不能の状 態が正常生活が営めるようになるまで改善した. 外科に 人院してからの治療期間は 1 年 6 力月, 副腎皮質機能の 正常化には 2 年 7 カ月を要した。白鳥ら”も上行結腸瘦 造設による重症例の治療効果を述べており，われわれは この考劣を参考にして特殊例のステロイド離脱に応用し たものである。

2 例目では，われわれは上行結腸瘦の代りに回腸末端 $10 \mathrm{~cm}$ 位の場所にループ回腸瘦を造設した（図6，7）. 回腸濱の方が造設が容易であり, 後のバック装着も容易

\section{图 6 回腸瘦造設法}

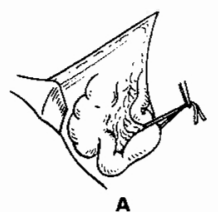

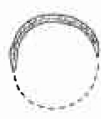

B

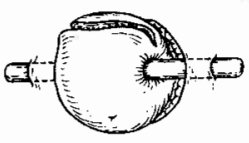

D

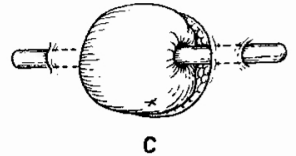

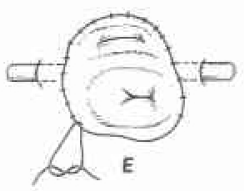

A：口側に目印をつける。形皮膚切開. $\mathrm{C}$ ：支持棒としてりプラスチック棒を皮下に通 す。目印のついた口側腸管は下方。 D : 肛門 側に答せて晹管を横切開. $\mathrm{E}$ ：全層一皮膚縫合 (Dexon 3-0). 側が突出する. 
図 7 術後 1 週間目の状態

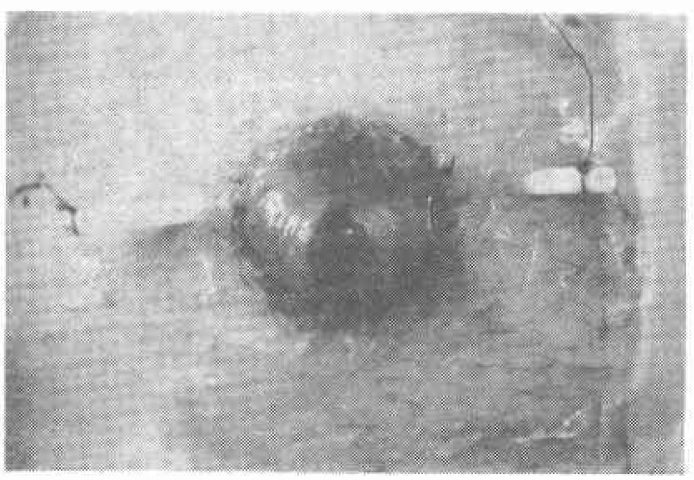

便は歌便で肛門側には進入しない。皮管はカラ ヤガムパウダーで保護。

である.プラスチック棒を皮下に通すことになり腸管全 層と皮膚の縫合が全周にわたって完全に行えること，腸 管の横切開を遠位側寄りにずらせて行らことにより，完 成した近位側口が Brooke 式の場合のように突出するの でバック装着が容易であることの 2 点が本法の利点と考 えられる、プラスチック棒は10〜14日後に拔去する。プ レドニン $20 \mathrm{mg}$ 投与中に造設されたも拘らず, 創治瘉は 速かで感染もなく，腸壁一皮膚縫合のみで何事も起こら なかったこの症例はステロイド離脱後に全結腸切除十 回腸直晹吻合を行ら予定である.

このよらな症例は潰瘍性大腸炎にステロイドによる医 原病が合併した特殊例であるために, その取り扱い方に ついての記載は教科書にも文献にも見当らない，われわ れの採った方法は時間はかかるが最す安全と考党られる 方法であるが，まだ十分な臨床経験を積んではいないの で今後る時間をかけて検討しなければならないだろう。 一期的に結腸切除を行うことは，余りにも危険が多すぎ て採用する勇気はない。しかしながら，より大切なこと はステロイド長期連用によってこのよらな症例を作らな いことであり，内科と外科の緊密な協力体制が望まれ る.

\section{3）直晹温存例の術後管理}

われわれの経験からあ明らかなよらに, 直腸を温存し た手術を行った場合には炎症の再燃の可能性が常にある ことを銘記しておかねばならない，患者る医師も再燃は ほとんど必発と考えて再燃した場合に適切な処置を探る 準備をしておくことが朋要である，術後直腸のチェック を定期的に行い軽度の炎症に対してステロイド坐薬，め るいはステロイド注腸を行う場合と, 術後放置したまま
の場合とでは, その予後が大幅に異なることが示されて いる5). 前者では再手術の率が5\%なのに比して, 後者 では84\%に及んでいる ある. 図 3-4の患者は直腸炎症の再燃が増悪したため に入院治療を必要としたことがあった、ステロイド坐薬 の使用法に十分慣れていなかったために治療が後手にな ったことが原因と反省した結果, 以後は再然の早期に大 量のステロイド坐薬 (プレドニン20〜 $40 \mathrm{mg}$ )を使用する よらにしたところに前のよらな強度の再然はみられなく なった．再然の頻度と程度は年々減少の傾向にある. 使 用したステロイド坐薬の量はかなりの大量にのぼるが， 経口投与に比して 経值腸投与からの吸収量のピークは 1/3〜1/4であるために，臨床的には副作用がほとんど認 められ京いとい5特徴がある8（图8）. われわれは現 在, 直腸温存例の再然に対してステロイド坐薬を用いて

図 8 プレドニン $20 \mathrm{mg}$ の経口投与と経值腸坐薬 投与による血中コーチゾール濃度の比較.

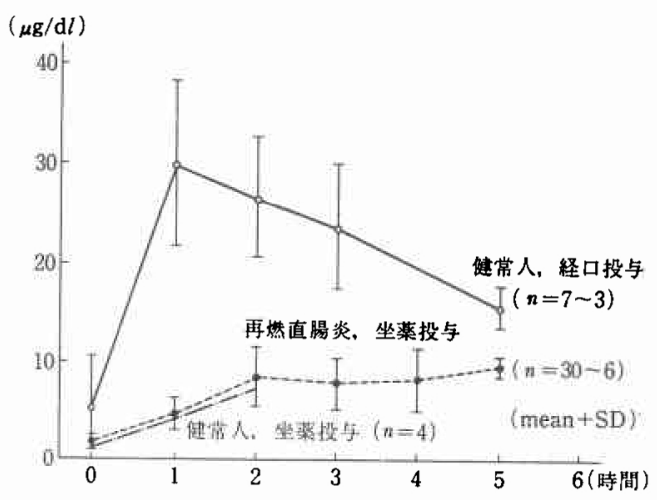

おり，再手術を必要とした経験はない。再然の初期に使 用すれば治漓期間も少なくすもが，资症が強度な場合に は思い切って大量(プレドニン $20 \mathrm{mg} \times 3)$ を用いること もある.治療法のコツは通常の直晹炎に対するコッと同 じである . 通常の投与法はプレドニン $20 \mathrm{mg}$ 坐薬から 始めて $10 \mathrm{mg} \rightarrow 5 \mathrm{mg}$ と減量して柱り，リンデロン $2 \mathrm{mg}$ 坐 薬，ハイドロニーチゾール $100 \mathrm{mg}$ 坐楽を用いることる ある・

臨床的に副作用が認められなくても, 回直腸粘膜から 吸収されている以上生体に何らかの影響を及ぼしている のは当然であり, 投与後の血中ューチゾール・レベルを 測定すると正常値以下に下降している例が見出されるこ とに1つの問題がある.しかし, 幸いなことに坐薬投与 を中止すると速がコーチゾール・レベルは正常に復す 
る.この問題については，今後とも一層の検討を要する と思われるが，ステロイド坐薬使用に際しては生体側の 反応を考虑に入れた慎重な態度が必要であると考えてい る.われわれは東大病院薬剤部の提供によってステロイ ド坐楽を使用しているが，欧米では日常診療で手に入る この薬剤がわが国では未だ市販されて批ず，必要と思 われる治療が十分に行なえない点にもう1つの問題があ ると思われる ${ }^{10}$

\section{4) Crohn 病の手術適応}

内科的および外科的療法を問わず, Crohn 病の治療法 は未だ確立していない，内科的治療によって Crohn 病 を完治させることは不可能であるし，一方，外科的治療 によって Crohn 病の根治を100\%期待することすできな (11). 手術的に病変部を切除しても再発率が高く, その 值は $3 \%$ \% $62 \%$ にわたっている ${ }^{12)}$. 再発率は長期観察

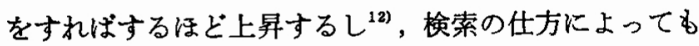
再発率の値は異なってくる。このように，手術の危険を 侵しても根治を確実に期待できないために, 手術的治療 は合併症がないかぎりできるたけ行わないといらのが， 現在の一般的な考光方のようである ${ }^{13316)}$. 合併症として， (1) 通過障害, (2) 瘦孔形成, (3) 出血, (4) 栄養障 害などがある.われわれの症例の一部はこれらの合併症 のために手術されたが，大部分は復部腫瘤のために診断 不確定のまま開腹術を受けた症例が多かった。われわれ の現在の考兄は一般の通念に準ずるるので, 著しい合併 症を有する例にのみ手術適応があると考えている。しか し, 最近 Crohn 病の早期発見, 早期外科的治療の考光 を持っている人るいるようである ${ }^{15)}$. 未だその評価は定 って括らず批判すべき十分な資料もないが，今後注目し てゆきたいと考兄ている。

手術々式としては合併症の原因となっていると考えら れる部分のみ切除する立場と, 再発の防止のためにでき るだけ広範に切除する立場とがある゙1)。一般的には主病 変の周用にある aphthoid ulcer を取り残すと再発すると 考えられており,これらの小病変も含めた腸切除が勧め られている.しかし，そのために short bowel syndrome が起きるほどの広範囲切除を行らことは妥当ではない。 広範に切除しても再発しないといら保証むない，局所 リンパ節をできるた゚け切除することが勄められている が，組織学的診断とくに腸結核との鑑別のためにる，リ ンバ節切除とその組織検索を忘れないことが大切である $5^{16) 17)}$ 。潰瘍珄大腸炎の場合々異なり, Crohn 病の場合 には手術的治療による根治が十分には期待できないため
に，手術は姑息的なるのにならざるをえない，手術々式 と再発形式の間に何ら関連性を見出すこともできなかっ た。日本での症例が增えたといってる欧米の尃門病院の 経験の $1 / 20$ 以下であり，当分の間はこれら信用のおける 専門病院の経験を参考にして治療方針を站てるのが得策 ではないかと考えている．われわれの将椡はいずれも主 病変の切除のみを主体にした姑息的手術が行われていた が, 再発例と非再発例に怙ける病変, 手術々式の間に差 はみられなかった。わが国においては Crohn 病の診断

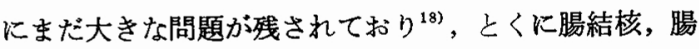
型ベーシェットなどの欧米では頻度の少ない疾患との鑑 別法は，わが国が独自に解淤していかなければならない 今後の課題であろ ${ }^{19)}{ }^{20)}$.

症例数が少なく，過去における手術例が多いために Crohn 病に関する検討は不充分なまをに終らざるをえな かった．各症例の経過を調査してみると，術後何年も経 って再発している例，他施設で診断不祥のまま診断され て再発時に Crohn 病の診断がついた例などが少なくな かった. Crohn 病は経過の長い疾患であるので, 診断, 治療, 予後についての検討は長期間にわたる息の長い追 跡調查に基ついたものであることが大切であると考えら れた。

\section{5. おわりに}

教室に和ける潰瘍性大腸炎ならびに Crohn 病の手術 成績を報告し，両疾患に対するわれわれの現時点での治 療方針，手術適応についての考え方を述べた。

手術適応のある潰瘍性大腸炎は可及的に直腸温存術を 行い, 残存直腸の再然に際しては, ステロイド坐薬を使 用することを原則としている。CCrohn 病は合併症のある 場合にのみ手術を行い，後に障害を残さない程度にでき るだけ病変部周囲を含めた範囲の切除を行らことが適当 であると考えている。

\section{参考文献}

1) 白烏常男活か：謴瘍性大腸炎㐿術症例の昭和50 年度全国調查について，厚生省特定疾患，潰瘍 性大腸炎クローン病調查研笕班昭和 50 年度業績 集, p. 14-19, 1976.

2) Goligher, J.C., et al.: Ulcerative Colitis. p. 223, Bailliere Tindall \& Cassell, London, 1968.

3) Lennard-Jones, J.E., et al.: Observations on idiopathic proctitis. Gut: 3 201-206, 1962.

4) Aylett, S.O.: Ileorectal anastomosis: Review 1952-1968. Proc. R. Soc. Med., 64: 967-971, 1971. 
5) Symposiunm: The dilemma of preservation of the rectum. Dis. Col. Rect., 20: 643-660, 1977.

6) Baker, W.N.W.: The results of ileorectal anastomosis at st. Mark's Hospital from 1953 to 1968. Gut, 11: 235-239, 1970.

7) 坂本栄一ほか：潰袮性大腸炎を母地として発生 した直腸癌の 1 例. 胃と腸，13:1113-1122, 1978.

7）白鳥常男ほか：重症溃涀性大腸炎に対する上行 結腸瘻の治療的意羡. 手術, 31：919-925, 1977.

8) 武藤徽一郎ほか：軽症型潰湐性大腸炎のステロ イド坐薬療法に関する臨床的ならびに基礎的研 究. 厚生省特定疾患. 潰瘍性大腸炎》ローン病 調查研究班昭和 50 年度業績集, 203-211,1976.

9) 武藤徵一郎ほか：非特異性直腸炎のステロイド 坐薬に上る治療経験。大腸肛聞誌, $29: 420$ 426, 1976.

10) Truelove, S.C.: Suppository treatment of hacmorrhagic proctitis. Br. Med. J., 11: 958, 1959.

11) Alexander-Williams, J.: Progress report. The place of surgery in Crohn's disease. Gut, 12:
$739-739,1971$.

12) de Dombal, F.T.: Recurrent Crohn's disease. Canad. J. Surg., 17: 408-000, 1974,

13) Kyle, J.: Crohn's disease. p. 164-185, William Heinemann Medical Book Ltd., London, 1972.

14）土屋周二ほか：クローン病の治療と予後. 胃と 晹, $13: 517-526,1978$.

15) Hildell, J.: 私信, 1978.

16) Morson, B.C.: Skandia International Symposia. Regional Enteritis (Crohn's Disease). p. 15-33, Nordiska Bokhandelns Förlag, Stockholm, 1971.

17）武藤徹一郎ほか：潰瘍性大腸炎との鑑别が困難 であった大腸結核の 1 例．胃と腸，12：1667一 $1673,1977$.

18）武藤徹一郎ほか：非特異性の炎症性大腸疾患の 病理一とくにCrohn 病を中心に一, 綜合臨床, $26: 1076-1088,1977$.

19）八尾恒良ほか：クローン病18例の分析よりみた 臨床診断とその問題点。胃と腸， $13 ： 315 一$ $334,1978$.

20）馬場正三：クローン病と晹型ベーチェットの鑑 別. 日本臨床, $35: 1906-1912,1977$. 